Article

\title{
Geological Features for Geotourism in the Zanjan and Hamadan Area, Northern Iran
}

\author{
Ardalan Afrasiabian ${ }^{1}\left(\mathbb{D}\right.$, , Siamak Mahmoudi Sivand ${ }^{2}$, Dragana Dogančić ${ }^{3} \mathbb{D}$, Lucija Plantak $^{3}(\mathbb{D})$ \\ and Bojan Đurin $4, *$ (D) \\ 1 Institute of Applied Geosciences, Graz University of Technology, 8010 Graz, Austria; \\ ardalan_afrasiabian@yahoo.com \\ 2 Water Research Institute, Tehran 1417466191, Iran; sivand57@yahoo.com \\ 3 Faculty of Geotechnical Engineering, University of Zagreb, 42000 Varaždin, Croatia; \\ ddogan@gfv.unizg.hr (D.D.); lucija.plantak@gfv.unizg.hr (L.P.) \\ 4 Department of Civil Engineering, University North, 42000 Varaždin, Croatia \\ * Correspondence: bojan.durin@unin.hr
}

check for updates

Citation: Afrasiabian, A.; Mahmoudi Sivand, S.; Dogančić, D.; Plantak, L.; Đurin, B. Geological Features for Geotourism in the Zanjan and Hamadan Area, Northern Iran. Sustainability 2021, 13, 6587. https:// doi.org/10.3390/su13126587

Academic Editor: Dmitry A. Ruban

Received: 16 April 2021

Accepted: 2 June 2021

Published: 9 June 2021

Publisher's Note: MDPI stays neutral with regard to jurisdictional claims in published maps and institutional affiliations.

Copyright: (C) 2021 by the authors. Licensee MDPI, Basel, Switzerland. This article is an open access article distributed under the terms and conditions of the Creative Commons Attribution (CC BY) license (https:// creativecommons.org/licenses/by/ $4.0 /)$.

\begin{abstract}
Iran is a land of complex geological past which reflects in its many natural wonders. There are more than 850 known caves in Iran with a total length not exceeding $1000 \mathrm{~km}$, many of them not being properly explored. Two of the biggest and most famous caves are Ali-Sadr and Katale-Khor. The Katale-Khor cave has a simple maze anastomotic pattern. Ghar Ali-Sadr is an anastomotic type of cave located $75 \mathrm{~km}$ northwest of Hamedan in a village by the same name and circa $60 \mathrm{~km}$ south of Katale-Khor cave. Ali-Sadr cave is considered to be one of the most unique and scenic caves in the world. One of the features that makes Ali-Sadr cave special is a fact that it is the longest and the biggest water cave in the world (from the point of the boating course inside the cave). This natural wonders in Northern Iran are great base for developing a geotourism, as a form of tourism that specifically focuses on geology and landscape. Its purpose is to promote an understanding of earth sciences through appreciation and conservation of geodiversity. The best way to achieve this is through visits to geological features and locations.
\end{abstract}

Keywords: karst cave; passages; karst spring; talars; Iran

\section{Introduction}

Caves have fascinated mankind from the earliest times. Caves provided shelter from the elements and became home for the first humans. Evidence for that is seen in numerous archeological remains found inside inhabitable caves. Cave drawings are both an evidence of artistic aspirations of the first modern humans, and a testimony of past times by being the first documentary depictions of everyday events and immediate environment. Nowadays caves are a window to Earth's interior and means to investigate unknown aspects of underground dynamics. Caves can be defined as underground spaces created by natural geological and geomorphological processes which are large enough to be examined in certain way by humans. The majority of caves have developed in the rocks which can be dissolved by a weak natural acid like carbonic acid which forms by absorption of $\mathrm{CO}_{2}$ by rainwater either in the air or in the upper layers of soil [1].

The growing interest of tourists to visit the caves and the development of speleology make the caves an attractive natural asset today [2,3]. Even at the moment, the underground world is still posing a mystery to most people who never visited it because it is believed to be (and is to some extent) dangerous. The underground exploration requires both special equipment and knowledge of the speleological techniques. However, the fascination of a strange and mysterious place, such as the underground, is the main impulse for people to partake in underground geotourism. Process of transformation of the cave in a show cave, suitable for visits of the tourists untrained in speleological techniques is complex and it 
requires modification of the underground space. The first step necessary to transform a natural cave into a show cave is to understand its unique significance from both aesthetic and scientific aspects. To enable entering visitors into the caves, one must ensure lights, ladders and staircases, bridges, handrails and pavements. Furthermore, sometimes it is necessary to widen the narrow passageways and to make connecting tunnels. All of these actions modify the natural arrangement of the cave in some extent [1].

Iran is a Middle East country with a rich cultural heritage and various natural beauties. Carbonate rocks cover about $185,000 \mathrm{~km}^{2}$ or roughly $11 \%$ of Iran's land area and present an important factor in water supply of many regions. Even though karst aquifers and springs are present in various carbonate formations, majority does not have a developed cave system. Arid climate was not a favorable condition for formation of mature karst and large well-developed cave systems. Rare multilevel caves have developed in some areas due to rapid tectonic uplift, folding and faulting of the terrain [4]. There are more than 850 known caves in Iran with a total length not exceeding $1000 \mathrm{~km}$; many of them not being properly explored. Two of the biggest and most famous caves are Ali-Sadr and Katale-Khor (Figure 1) [5]. Both of them are developed in areas with rare surface karst landforms and genesis of caves by meteoric sinking streams seems to be unlikely case [6].

Tourism still does not have a big role in Iran's economy, with religious tourism being the most dominant type. Ecotourism and historical tourism gains momentum in some parts of the country but it is far from using its full potential. Iran is a country with exceptional history but also has the significant geological phenomena and diverse landscapes, thus giving a base for a broad range of tourism activities [1,7]. Geotourism is a new and innovative branch of tourism which promotes both environmental and social responsibility and is becoming more and more widespread [8]. One can define geotourism as a form of tourism that specifically focuses on geology and landscape. Its purpose is to promote an understanding of earth sciences through appreciation and conservation of geodiversity. The best way to achieve this is through visits to geological features and locations. Unlike other forms of tourism, geotourism takes place mainly in natural areas, wherever there is a geological site [9,10]. Herrera-Franco et al. [11] state that geotourism must fulfill five basic principles. It must be geologically based (geoheritage) and sustainable (geoconservation) with an educational purpose (geointerpretation). Furthermore, it must bring benefits at the local level and provide tourist satisfaction. However, it is imperative to consider that popular geotourism destinations face the same challenges as other tourism destinations, such as overcrowding and a wide range of negative impacts on geoheritage and on the vegetation and wildlife of these destinations [12]. The connection between tourism and geosites is definitely a multifaceted one, resulting from the economic focus of tourism on one side and the preservation efforts of protected areas on the other side [13]. Lately, a new concept arises, called cultural sustainability, which is the concept for the improvement and protection of cultural identities. It is in line with traditional practices and celebrates local and regional histories and passes down cultural values for generations to come. Geoparks represent an innovation in the protection of natural and geological heritage and play an important role in cultural sustainability in rural areas. Additionally, a geopark promotes local socio-economic and socio-cultural development by attracting an increasing number of visitors [14].

When we talk about tourism, it is very important to emphasize the importance of sustainability of all aspects of tourism activities. Caves are naturally very vulnerable environments, due to their isolated nature, their relatively stable environments and their direct reliance on the activities conducted at the surface directly above and in the recharge area of the caves. Rising number of visitors can pose a threat to sensitive parts of the landscape. Ahmadzade and Elmizadeh [15] found that maximum presence of tourists in the Katale-Khor and Saholan caves disrupted the formation of the speleothems due to change in the microclimate. Facilities that are an integral part of the tourist offer can often become a source of contamination. This is especially pronounced in the karst areas where a thin or non-existent ground cover facilitates the infiltration of water and contaminants 
to groundwater. This is particularly important nowadays when Iran is turning itself to possible usage of karst aquifers for water supply [15]. Show caves have a wide range of different management plans, from high-impact activities reserved for tourists in caves, to simple visits with minor changes to the natural environment [16]. Each cave has a specific flux (or number of visitors in time unit) tolerance limit. Nowadays, people are aware that show caves are impacted by tourist development and that they must be under constant monitoring in order to prevent any detrimental consequences of human activities.

Geosites and geotourism have been the topics of a growing number of studies and articles [12]. Zgłobicki and Baran-Zgłobicka [17] found that landscape (aesthetic) values were the main motive for the tourist visits and the sites of great scientific and cognitive value did not stimulate the interest of tourists. Furthermore, authors found that the understanding of a given area results in a better rating given to it by tourists. These findings are similar to ones from [18] which observed that Iranian geotourists deemed the rarity of a geosite and the number and quality of viewpoints as most important reasons for visit. The promotion of valuable geological sites should be part of bigger projects meant to develop tourism in poorly developed areas. Geomorphological heritage sites are usually visited during visits to well-known tourist destinations. It often occurs that the interesting geomorphosites are little known, even though they are located quite close to the famous tourist centers because the wish to learn more about the assets of inanimate nature is seldom the main goal of the tourist visits.

Geotourism, if established correctly, can also have a somewhat protective purpose on the environmentally sensitive areas, since it draws attention from well-known destinations making it "more eco-friendly than ecotourism per se" [19]. Experiences from areas with longer tradition in geotourism show that the distribution of discoveries and their scientific significance to local communities, combined with actions to raise perception of the need to safeguard natural and cultural sites leads to establishment of successful geosites. Furthermore, it is very important to form a partnership between different groups within academia with diverse research interests and local authorities. The participation of numerous local stakeholders in geotourism projects which aim to conserve and capitalize upon the natural and cultural heritage of the region by means of education and tourism is essential [20].

Even though in terms of tourism both Ali-Sadr cave and Katale-Khor cave are very remarkable and popular, from the geological perspective there has been only few investigation of cave genesis and characteristics, other than detailed mapping, especially the role of hypogene processes in their formation [6]. In order to build a strong foundation for a thriving geotourism industry and make these geosites attractive to visitors it is important to understand all the aspects of the caves, the surrounding areas and the possible impact tourist can have on it [10]. Therefore, our main mission was to examine characteristics of the abiotic landscape in order to go form qualitative to quantitative understandings. This information is known for some geological environments, but for the majority, these research data are missing. Better understanding of the natural phenomenon and its presentation to visitors can promote these geosites outside the borders of the provinces Hamedan and Zanjan.

\section{Materials and Methods}

\subsection{Geographical and Geological Characteristics of the Location}

Iran has a complex geological past that is reflected in the complex structure of the present geological formations. Southern and western parts of the Iran are parts of the Arabian plate, Cimmerian microplate makes northern and eastern parts and northeastern margin of Iran is a part of Eurasian plate [21]. 


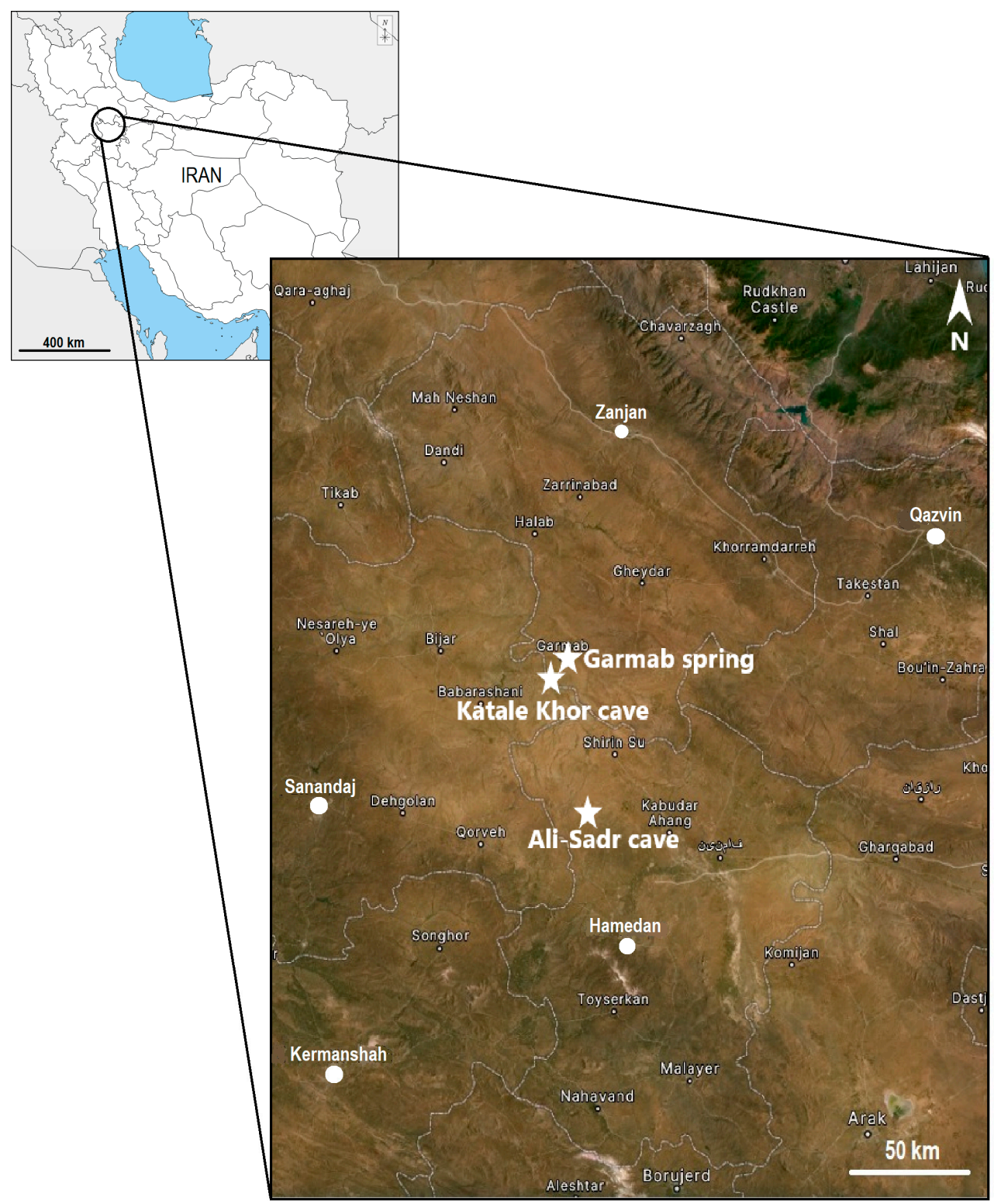

Figure 1. Map of Iran and position of the study locations (adapted from [22,23]).

The Central Iran is a complex triangular-shaped region of the interior Iranian Plateau (Figure 2). It is consisted of several microcontinental blocks and is bounded by the marginal fold-and-thrust belts of the Zagros and Makran in the south, the Alborz and Kopeh-Dagh in the north, and the Sistan accretionary wedge in the east [24]. As a result of the ongoing convergence between the Arabian and Eurasian plates, this area is subjected to a constant continental deformation $[25,26]$. In the basement of the Central Iranian Province lies a Cimmerian miniplate which is overlain by late Cretaceous to early Miocene magmatic rocks of Urmieh-Dokhtar magmatic arc. Thick layers of volcanic rocks, evaporites and turbidites were formed during Eocene back-arc extension across Central Iran. This sequence is usually superimposed by Oligocene terrestrial clastites, evaporites and volcanic rocks of the Lower Red Formation. Marine deposition continued throughout larger part of Central Iran with the carbonates of the lower Miocene Qom Formation which is overlain by middle Miocene terrestrial clastites and evaporites of the Upper Red Formation $[27,28]$. The Central Iran is dominated by narrow mountain ranges and intermontane depressions. The mountain ranges and the lowlands of Central Iran are divided by deep-seated reverse and strike-slip faults [29]. 
The Qom Basin covers the western parts of central Iran and was formed in the Late Oligocene by marine transgression. The Qom Formation consists of a thick succession of marine marls, limestones, gypsum and siliciclastic rocks. It overlies the Lower Red Formation and Eocene volcanic rocks. The Qom Formation is overlain by the Upper Red Formation consisted of non-marine siltstones and evaporite-dominated beds [4,30-32].

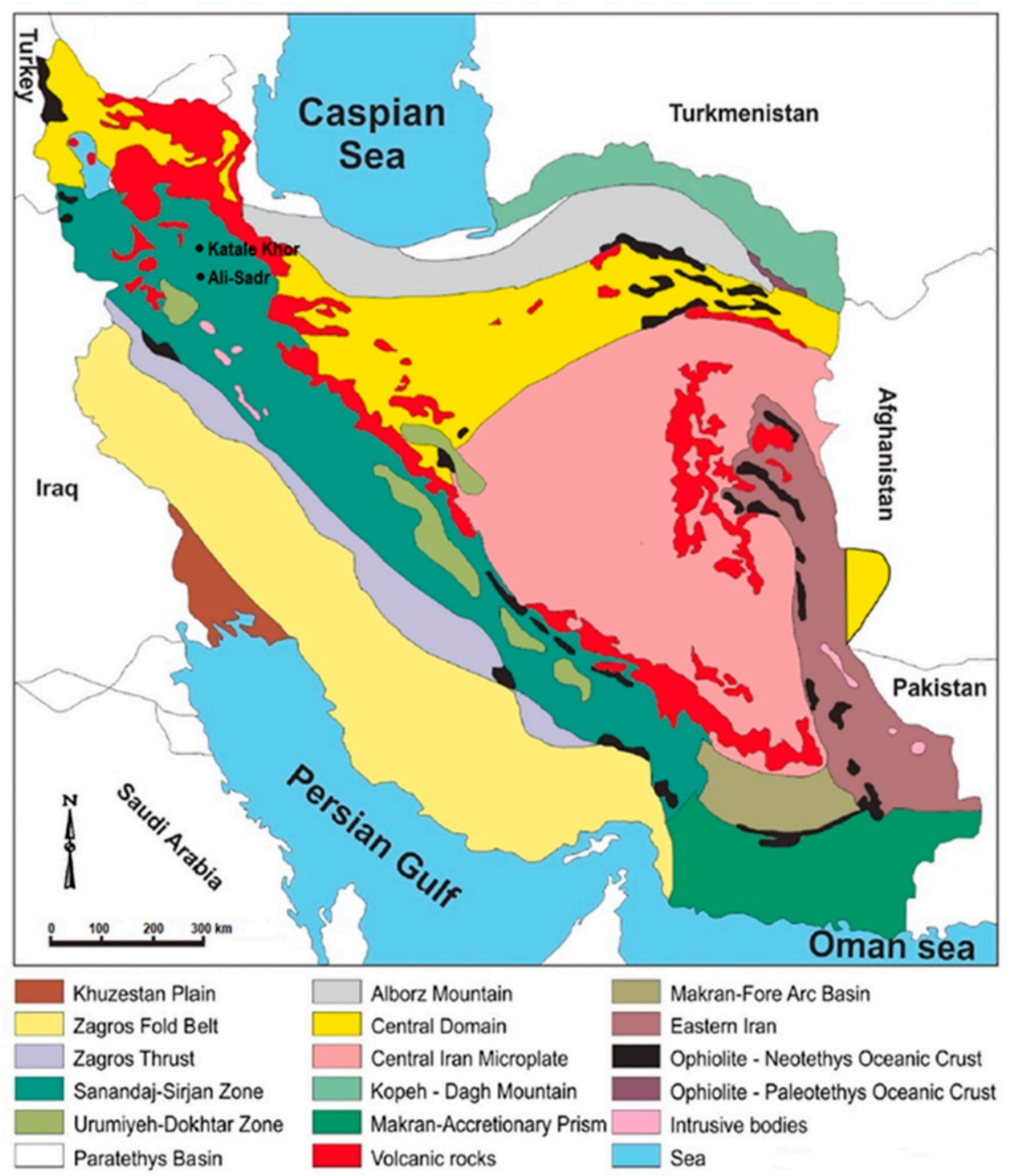

Figure 2. The structural map of Iran with the position of the investigated caves (adapted from [18,33]).

Southeastern region of Zanjan is part of the northwestern part of Central Iran. The average height of the province is about $1600 \mathrm{~m}$ with a total area of $22,150 \mathrm{~km}^{2}$.

As stated, only $11 \%$ of the Iran is underlain by carbonate rock formations, mainly in a broad western belt, in the northeast and central parts. Geomorphological studies have determined evident differences between the size of karst landforms in arid Central Iran and the more abundant karst in more humid regions such as the Zagros. Majority of the famous and important caves like Ali-Sadr and Katale-Khor have developed in areas with rare surface karst landforms where cave genesis by meteoric sinking streams seems to be improbable. Hypogene caves are found mainly in the Northwest, the Central and Eastern zone, where they are associated with the igneous activity, and the Zagros zone. 


\subsection{Climate}

Based on the data from 1990-2014, 9 out of 31 possible Köppen-Geiger climate types are present in Iran. Most parts of central, eastern, and southern Iran are classified as BWh and BWk climate types. The coastal areas next to the Caspian Sea and most parts of mountainous areas of Zagros and Alborz in west and north of Iran have moderate climate type (Csa). The eastern slopes of Zagros and southern slopes of Alborz that are connected to the central arid and semi-arid climate of central Iran are categorized as BSk climate. The southern parts of Zagros region are generally dominated by BSh climate. Dsa and Dsb climate types can be found in several parts of mountainous areas of Zagros and Alborz, while Csb and Cfa are the localized climate types that can be observed in coastal areas of the Caspian Sea [34]. Zanjan is one of the coldest regions in Iran with an average daily temperature during warm period of only $20^{\circ} \mathrm{C}$. According to Köppen-Geiger climate classification, this area is classified as DSa and DSb [35]. The Ds climate types are snow climate with dry summers. The third letter designates hot (a) or warm (b) summer. The Ds climate types are very vulnerable to change and shift. Lately, the Dsb climate type tends to shift into Dsa climate types. Furthermore, it was noticed that the Ds climate types in western Iran tend to be substituted by Csa climate type. The evident shift from Ds or Csa climate types into BSk climate type is seen in northwestern Iran. This indicates a rapid and extensive desertification in northwestern Iran due to global climate change [34]. The Zanjan region has a semi-arid climate, and the average annual rainfall is $300 \mathrm{~mm}$ [6]. Due to the warmer temperatures the best time for traveling and exploring geotourism locations is from June to September.

According to [36], the northern and western mountainous areas have somewhat regular precipitation distribution during the year, while southern areas have a strong seasonality. The precipitation occurrences move back from south to north from April to September, being limited to the Caspian Sea region in August and September. What one might call the 'wet season' extends from November to April. Only one substantial flood event has been reported during the past twenty years. Vegetation is sparse, except around oases maintained by groundwater. Farms and small villages get water from historic systems of "qanats", drainage capture tunnels dug long and deep into the alluvial fans and other deposits.

\subsection{Methods}

For the purpose of the research, samples of the drip water from the Katale-Khor cave and Garmab spring waters were collected. Since the upper floors of the Katale-Khor cave are dry the samples were taken from the 4 permanent water drips. An automatic water sampler was designed for drip water collection in a $60 \mathrm{~mL}$ PVC bottle each hour. Every $24 \mathrm{~h}$, the electrical conductivity (EC) and $\mathrm{pH}$ of the samples were measured by a WTW Multi 340i instrument and a WTW MultiCal pH-540 m on their arrival in the laboratory. Based on the variations in EC, some typical samples were chosen for chemical analysis by ion chromatography (Methrom 761 Compact IC) which included: $\mathrm{K}^{+}, \mathrm{Na}^{+}, \mathrm{Ca}^{2+}, \mathrm{Mg}^{2+}$, $\mathrm{SO}_{4}{ }^{2-}, \mathrm{Cl}^{-}$and $\mathrm{NO}_{3}{ }^{-}$ions. Samples selected for chemical analyses of major ions were refrigerated at $5{ }^{\circ} \mathrm{C}$ and analyzed within $48 \mathrm{~h}$ after collection.

$\mathrm{X}$-ray diffraction analysis (XRD) is a very useful and rapid technique that provides information on phase composition and crystal structure of the material. Mineral identification is based on d-spacing and relative peak intensities and is much easier if a sample contains only one type of the mineral. One of the major limitations of XRD technique is the detection limit, which is just about $1 \%$ of weight [37].

The mineralogical composition of ground rock samples was determined by X-ray diffraction (XRD) analysis using a MAXima X XRD-7000 X-ray diffractometer. An internal standard was added to each of the samples. Internal standard materials include corundum, zincite or rutile and are selected according to which material yields the least interference with the sample mineralogy. Three grams of the sample/internal standard powder were placed in a McCrone Micronizing mill with $15 \mathrm{~mL}$ of 2-propanol and processed for $4 \mathrm{~min}$. 
The mill reduced the particle size to approximately $1 \mu \mathrm{m}$. The mixture was left to dry overnight, and then the powder was collected for X-ray analysis. The mineralogical identification was based on the comparison with a database.

Data precipitation values were collected in available meteorological measurement stations. Water flow values were obtained by measurement instrument.

\section{Caves and Springs Characteristics}

\subsection{Katale-Khor}

With an explored length of $12,860 \mathrm{~m}$, Katale-Khor cave is the longest cave in Iran. It is developed mainly within the Oligocene/Miocene Qom limestone in the northern flank of an anticline of Saghez-lou Mountain (Figure 3). The cave's mouth stands 6-8 m above a dry river (Figure 4). The name of the cave, Katale-Khor, means "mount of the Sun" in Persian. Katale-Khor is a multistage cave with three levels ranging from 1670 to $1742 \mathrm{~m}$ above mean sea level. There are two visiting routes inside the cave: $3 \mathrm{~km}$ open to the public and another $4 \mathrm{~km}$ available only for experienced cavers. Tourists can visit $2850 \mathrm{~m}$ of the cave on the first floor. Cave levels have been developed due to fluctuation of the water table. The cave was mainly created by phreatic corrosion in a still water environment. The floors of the cave are almost horizontal and are connected by relatively vertical wells.

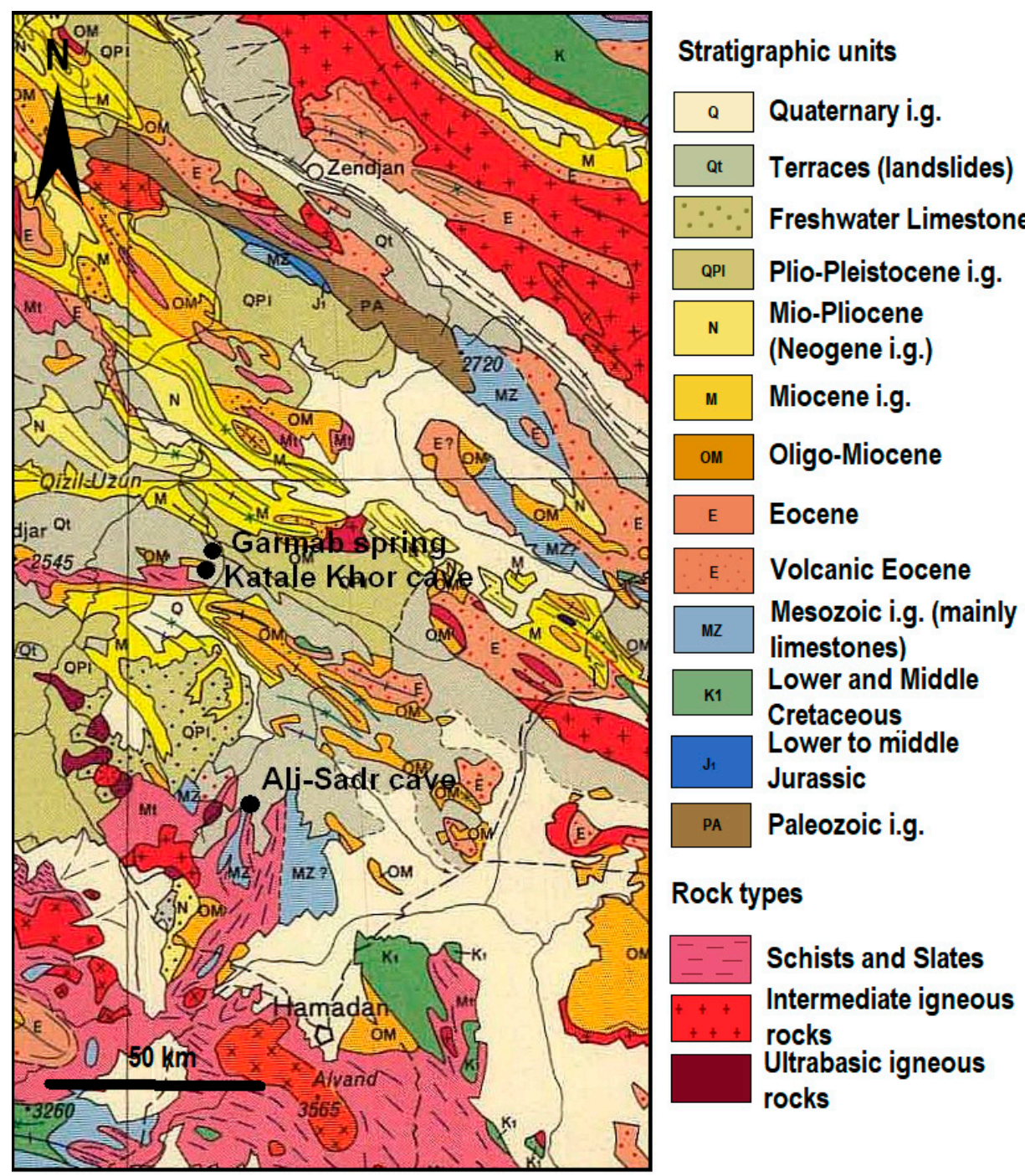

Figure 3. Geological map with position of Katale-Khor cave, Ali Sadr cave and Garmab spring (modified after [38]). 


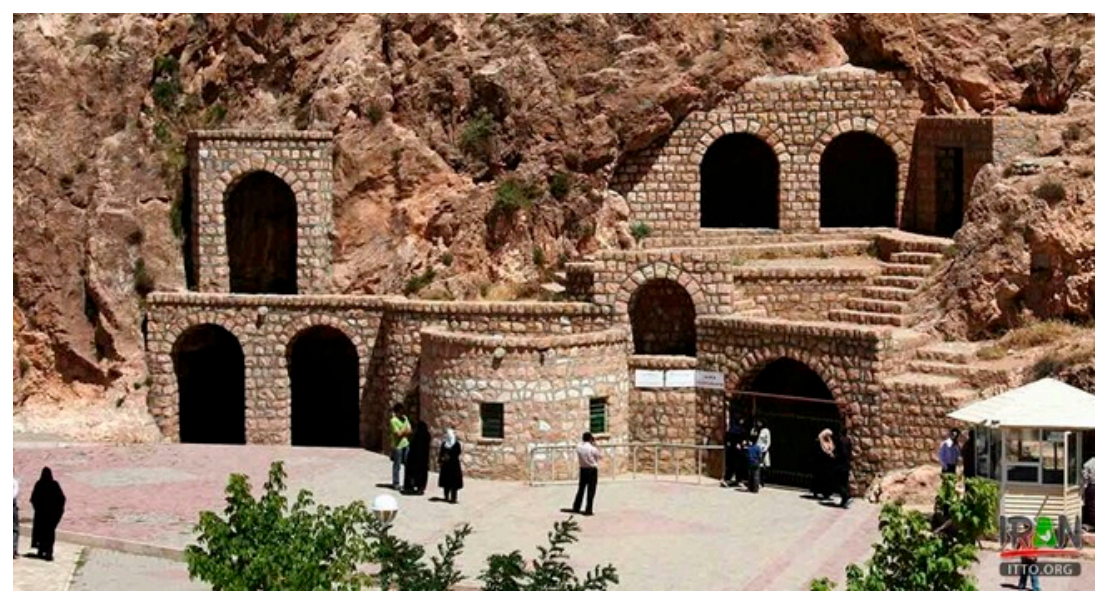

Figure 4. The entrance of the Katale-Khor cave [39].

The cave is famous for its beautiful cave deposits. Stalagmites, stalactites and limestone columns are found in abundance in the middle areas of the cave. Probably the most attractive part of the cave is the hall called Persepolis which contains many columns with a diameter of more than one meter and a height of $10 \mathrm{~m}$. In the Parvin hall, visitors can see curtains, shells and aragonite flowers. Calcite speleothems (stalactites, stalagmites, columns, flowstones and helictites) occur locally in the zones of water percolation from overlying formations. The fractures in the overlying limestone layers allowed the entrance of the precipitation in the cave system. The changes in carbon dioxide concentrations caused deposition of stalagmites, stalactites, columns, etc.

Katale-Khor cave has different origin than Ali-Sadr cave. According to previous studies, Katale-Khor cave is an anastomotic maze cave. The evidence demonstrates the floodwater origin of Katale-Khor cave [6]. Rezaei et al., as well as Mahmoudi Sivand and Bgherinejad, have suggested an epigenic speleogenesis [40,41]. Three distinct levels of cave passages have formed during the lowering of the water-level. The drops of the water levels were fast and approximately $25 \mathrm{~m}$ each. In the periods between drops developed flat-roofed passages, with V-shaped cross sections typical of convection along the ceiling and the walls of galleries immersed in $\mathrm{CO}_{2}$-riched solutions. The elliptical, rectangular and T-shaped sections indicate the saturation conditions at first and then-with a decrease in water level - the channel conditions at the time of cave formation. Unlike in Ali-Sadr, the source of the $\mathrm{CO}_{2}$ was meteoric water that recharged from the anticline range. Ahmadzade and Elmizadeh [15] propose different theory of speleogenesis. They claim that ascending deep waters of magmatic origin may have played the principal role in the cave development. After a while, the recharge from the magmatic source was slowly reduced and the succeeding, epigene processes created the current form.

\subsection{Ghar Ali-Sadr}

Ghar Ali-Sadr is an anastomotic type of cave located $75 \mathrm{~km}$ northwest of Hamedan in a village by the same name and circa $60 \mathrm{~km}$ south of Katale-Khor cave.Ali-Sadr cave is considered to be one of the most unique and scenic caves in the world. One of the features that makes Ali-Sadr cave special is a fact that it is the longest and the biggest water cave in the world (from the point of the boating course inside the cave) (Figure 5).

The cave is $2500 \mathrm{~m}$ long, with the depth of water reaching $8 \mathrm{~m}$ in some parts. The lake water is fresh and transparent, and the cave has many cavernous phenomena together with a range of colorful stalactites. The tourists can explore the cave by pedal boat and on foot and the presence of nearby accommodation adds to this recognized geotourism product [42]. The cave is developed in crystallized limestones and Jurassic schists (Figure 3). The origins of the cave are not precisely identified but most likely cause for development 
of the cave lies in the differential solubility between the hard schists and layers of soluble limestone. The length of the cave is about two kilometers.

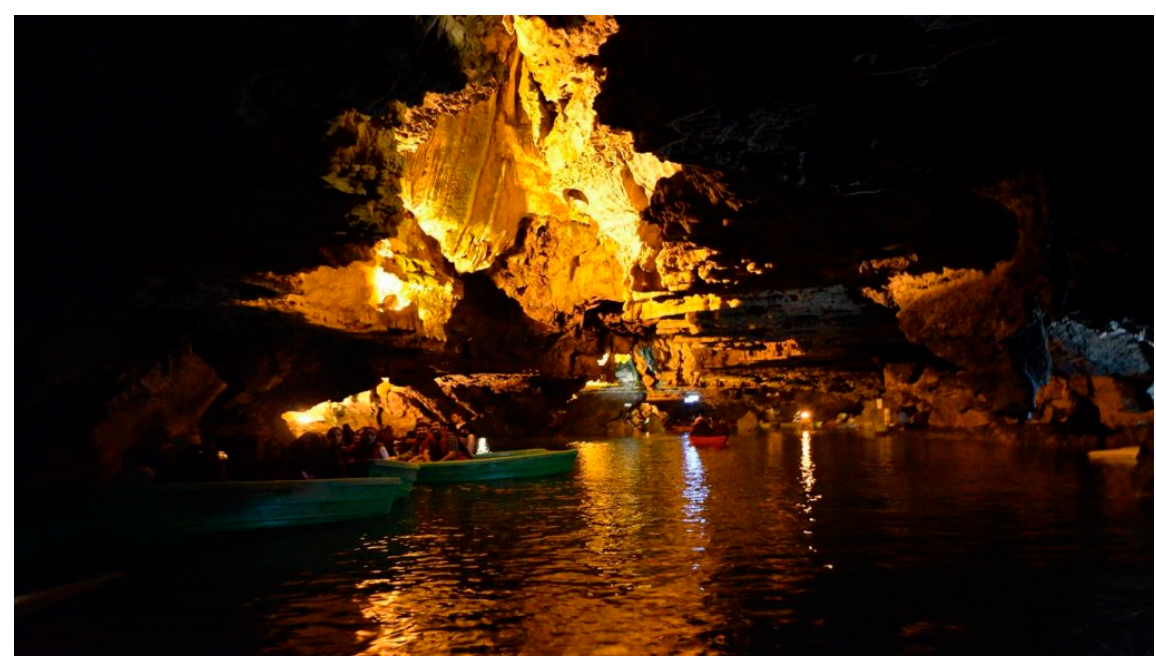

Figure 5. Inside of the Ali-Sadr Cave [43].

Ali-Sadr cave is located in a large anticline with a main axis orientation in a northsouth direction. The layers in the cave are at 40 to 45 degrees. The maximum height of the Ali-Sadr field is $2180 \mathrm{~m}$ above sea level, and the cave entrance is at $1980 \mathrm{~m}$.

The development of both caves is affected by fractures and faults. Narrow karst passages developed along larger fractures. Their predominantly oval cross section indicates a karst dissolution during seasonal saturation or flooding. The existence of irregular surfaces in both caves implies that water has dissolved paths in the areas where the carbonate rock was weakened by fractures and had more impurities, like $\mathrm{MgO}$, in composition. Unlike in Katale-Khor, caving did not play an important role in formation of Ali-Sadr cave.

The temperature of the cave water is approximately $12{ }^{\circ} \mathrm{C}$, and with a $\mathrm{pH}$ value of 7 , the water is nearly saturated with calcite. The water table varies every year by around $0.5-1 \mathrm{~m}$, with a maximum in late spring to early summer when some water can even spill to a spring [6].

Ali-Sadr Range is an isolated, steep ridge in the middle of alluvial fans and plains. It is part of the western structural units of the Central Iran zone. Horizontally bedded limestones and marls of Eocene to Oligocene age overlay the folded Jurassic limestones and schists. The main fracture directions created during the uplift of the limestone sequences determine the pattern of cave passages in Ali-Sadr Cave which follow the strike of the very steeply dipping beds. The bedding planes and joints were expanded by phreatic solution but due to continuous uplift which caused drainage they remained small in size [6]. In the period of cave formation, circulation of groundwater in the Ali-Sadr cave aquifer was slow to almost stagnant circulation. The main evidence for that is the lack of passages with canyon-like or tube-shaped cross sections which form during vigorous vadose or shallow phreatic water flow [44]. Calcite shelfstones found un the Ali-Sadr cave suggest $3 \mathrm{~m}$ of oscillation of the pool surface over the last 25,000 year or so. Reason for this can be cooler climate conditions in the Pleistocene and to some extent in human regulations of a scarce water resource [45]. Nowadays, the only recharge is occasional rain onto the limestone [46]. According to [44], since no specific speleogenetic studies have been done so far, the specific dissolution mechanism involved is still elusive. Based on current information about cave morphology, it is probable that Ali-Sadr is of hypogenic transverse speleogenesis. One of the natural phenomena in the area that supports this thesis is the Gorgoloh, a major spring approximately $20 \mathrm{~km}$ south of Ali-Sadr Cave. The spring is famous for the large amount of $\mathrm{CO}_{2}$ that emerges mixed with the water. The large amount of autogenic $\mathrm{CO}_{2}$ enables groundwaters to dissolve carbonate rocks. Stream that flows from the Gorgoloh spring 
precipitates travertine, encrusting moss, cyanobacteria and other organic material. It is a sign that cave formation process continues today and that the acidic waters form new cave systems at the present time by dissolving carbonate. Furthermore, aragonite mineralization is present inside Ali-Sadr Cave [47]. Higher temperatures can promote crystallization of aragonite $[48,49]$. Since the cave temperature is only $12{ }^{\circ} \mathrm{C}$, higher temperatures needed for aragonite formation could be caused by ascent and activity of deep hydrothermal waters.

Classic karstification does not appear to have an important role in the area surrounding the cave, since no epigene caves or karst features can be found above the groundwater level. Possible reasons might be lack of substantial vegetation and thick soil due to the semiarid climate which are generally the main source of $\mathrm{CO}_{2}$ for rainwaters that seep into the ground. All of this makes Ali-Sadr cave an attractive scientific object because it can be used to study cave formation under the influence of ascending $\mathrm{CO}_{2}$.

\subsection{Garmab Springs}

Garmab is a city in Khoda Bandeh county, in the south-eastern part of Zanjan province, with a population just over 3000 inhabitants. In the city and its vicinity there are two karst springs. The special attraction of this rural area are the hot springs as well as the KataleKhor cave. The climate is a mountainous with cold, snowy winters and moderate summers.

A karst aquifer has been formed in the Qom formation. The water level in this aquifer is currently lower than the level of the cave. The groundwater from the karst aquifer comes to the surface at two springs. The Garmab karst spring emerges from the eastern end of the Qom Formation and has an average discharge of $84 \mathrm{l} / \mathrm{s}$. The other spring is located inside the city of Garmab and has an average discharge of 30 1/s.

\section{Results}

Figure 6a presents the chemical composition of drip water sampled in the Katale-khor cave while Figure $6 \mathrm{~b}$ presents the chemical composition of waters from Garmab springs. All values are expressed in meq/L.

a)

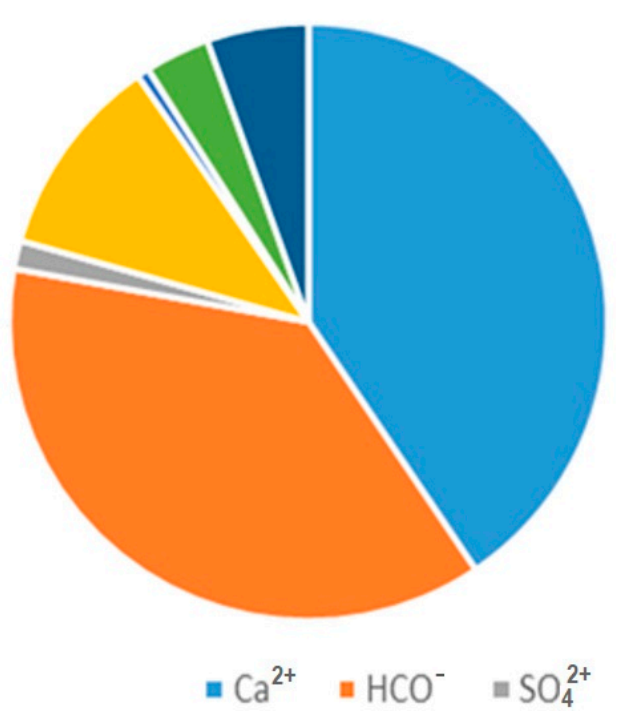

b)

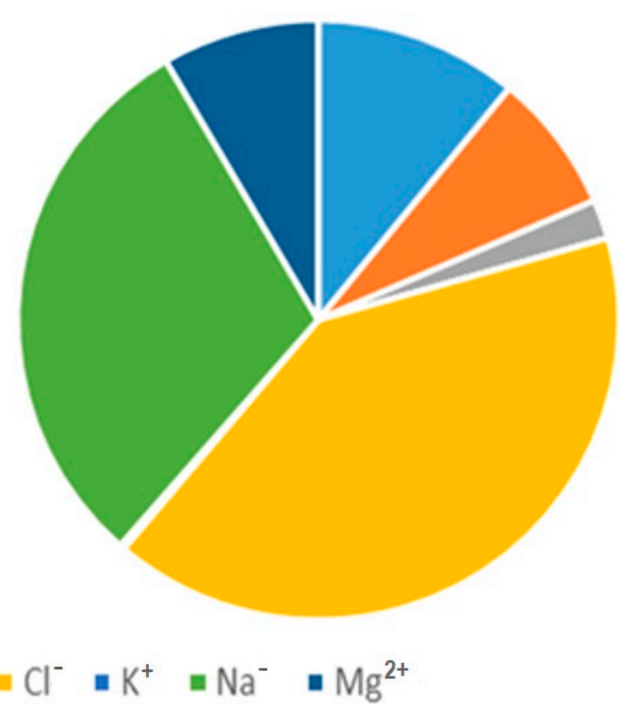

Figure 6. (a) The chemical composition of drip water in the Katale-Khor cave, (b) The chemical composition of waters from Garmab springs in meq/L [50].

Figure 7 presents discharge hydrograph of the Garmab spring along with the precipitation for the two consecutive months (August/September). 


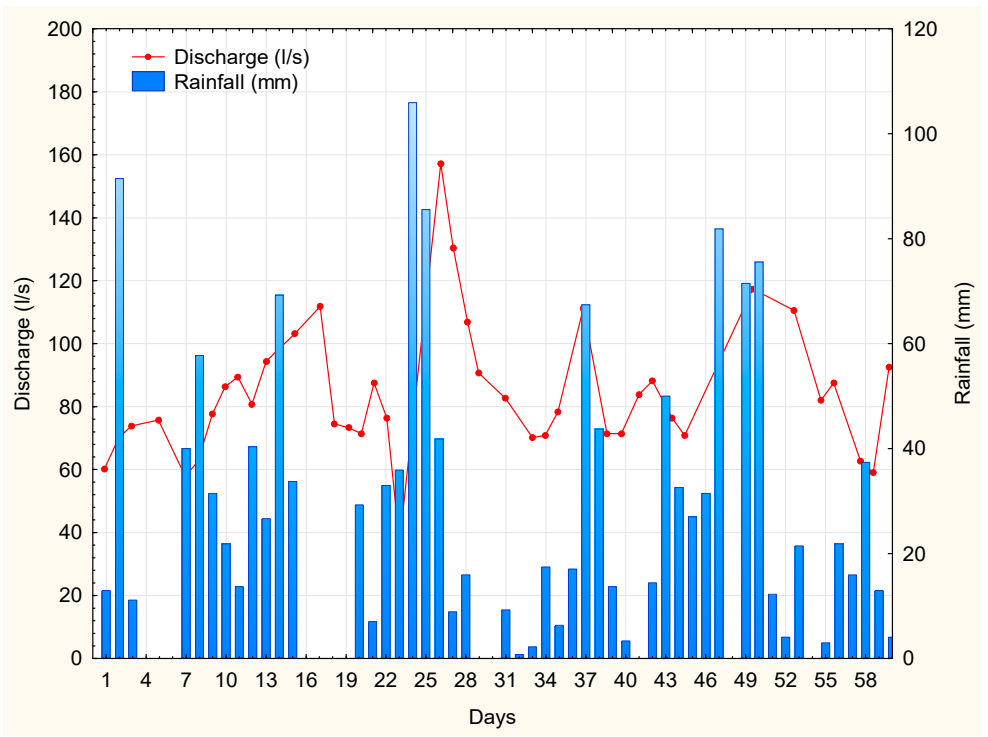

Figure 7. Discharge hydrograph of the Garmab spring for two months (August/September) [50].

Figure 8a presents results of the XRD analysis performed on the sample K- 1 taken from the Katale Khor cave. Figure $8 \mathrm{~b}$ shows the same analysis performed on sample A-2 taken from Ali-Sadr cave.
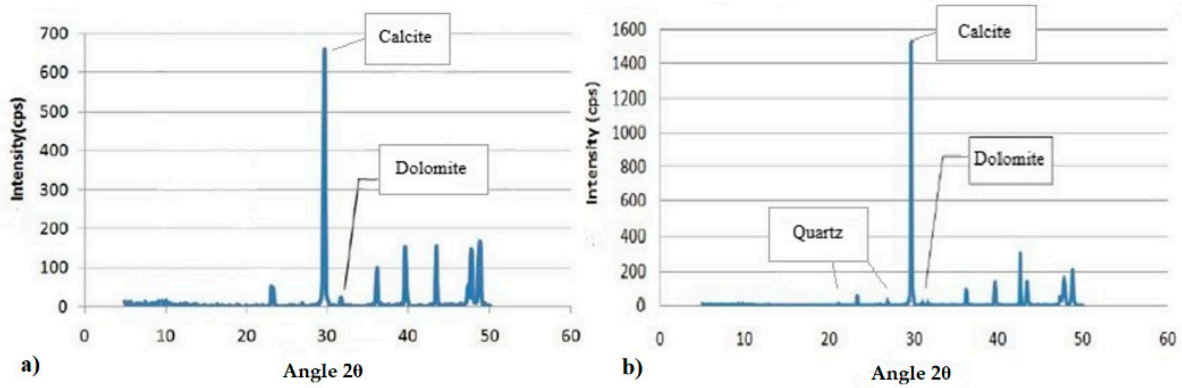

Figure 8. Results of the XRD test on the sample K-1 (a) and A-2 (b) [47].

\section{Discussion}

Better standard of life together with the increase of mobility, education and leisure, dramatically increased geotourism in the last two decades [17]. The main goal for a success of geotourism is to reconcile, on the one hand, the conservation of the natural resources and, on the other hand, support the opportunities for the development of recreation and tourism. The knowledge about all the characteristics of natural resource is helpful when establishing a suitable product that takes into account the needs of both parties: the tourists and nature. Better understanding of the natural phenomenon leads to the better preparation of the geosite for the tourist flow and also can alter the perception tourists have of the product [13].

When we talk about caves one of the most important factors is understanding of the process of the cave formation. The caves are inseparable part of their surroundings, many of them being part of the much larger and more intricate geological and hydrogeological complex. Tourists see only one aspect of the cave-its aesthetics. In order for tourists to be able to get acquainted with all the features of the cave in an entertaining and interesting way, it is necessary to constantly fill possible gaps in knowledge through detailed research. One of the parameters that can shed a light into connection of the cave and the surface is a cave drip water. Chemical composition of the cave drip water is complex due to the surface meteorological circumstances and the heterogeneity of water movement in the karst unsaturated zone [51]. Water conductivity is directly related to the concentration of 
ions in the water which comes from dissolved salts and inorganic materials such as alkalis, chlorides, sulfides and carbonate compounds. The EC of the drip water is $240 \mu \mathrm{m} / \mathrm{cm}$.

In the karst rock, drip water conductivity is controlled by the partial pressure of $\mathrm{CO}_{2}$ $\left(\mathrm{pCO}_{2}\right)$ and the dissolution of bedrock. Within the cave, the partial pressure of $\mathrm{CO}_{2}$ in the cave air has the dominant effect. The drip water chemistry is a site-dependent characteristic based on the variants in water residence time inside the aquifer, the amount of water mixing inside the aquifer and prior calcite precipitation [52-54].

The upper floor of the cave is dry, the drip water and cold vapors being the only sources of the water. The $\mathrm{pH}$ of the drip water sample was 7.7 making it slightly alkaline. This is normal in karst areas due to the presence of carbonate and bicarbonate ions in waters. Total hardness is $105 \mathrm{mg} / \mathrm{L}$ making the water moderately hard. Elemental chemistry differentiates water sources and allows the reconstruction of the underground fracture network from the place where the water infiltrated to the outlets. The chemical analysis of drip water in the Katale-Khor cave and Garmab spring is shown in Figure 6. As can be seen from the diagrams, dominant ions in the drip waters are $\mathrm{Ca}^{2+}$ and $\mathrm{HCO}_{3-}$ as is to be expected from the waters circulating through carbonate rocks. Smaller concentration of magnesium could be from dissolution of dolomite, a common mineral in carbonate rocks. Spring water, on the other hand, has a significant amount of sodium and chloride ion in its composition. Magnesium and calcium ions are present also, as well as hydrogen carbonate and sulphate ions. This could indicate a mixing of waters. Garmab spring water has $\mathrm{pH}$ 7.7, the same as drip water from Katale-Khor cave. Conductivity is significantly higher $(2300 \mu \mathrm{S} / \mathrm{cm})$. The total hardness is also higher $(392 \mathrm{mg} / \mathrm{L})$, making Garmab spring waters very hard [47]. Mohammadi et al. conducted chemical analysis of the water taken from Ali-Sadr cave [55]. The analysis revealed that the major cations in the water are $\mathrm{Ca}, \mathrm{Mg}$, $\mathrm{Na}, \mathrm{Si}, \mathrm{K}$ and $\mathrm{S}$ and the main anions are $\mathrm{HCO}_{3}{ }^{-}, \mathrm{SO}_{4}{ }^{2-}$ and $\mathrm{Cl}^{-}$. Water from Ali-Sadr cave is $\mathrm{Ca}-\mathrm{SO}_{4}$ type.

The data presented in Figure 7 shows water discharge quantities at the Garmab spring for two months timespan (August and September). The ratio of flood discharge to baseline discharge reaches a maximum of 3 . The discharge of these springs does not change much during rainfall. This means that below the current water table the karst features are not as developed as in the higher parts of the karst aquifer. Different hydrogeological parameters, such as recession coefficients at the surrounding springs, show low karstification of the aquifer. This is in dissonance with well-developed surface geomorphological phenomenon, like caves, shafts and big talars, which implicate higher degree of development of subsurface karst.

Figure 8 shows XRD results of samples of both presented caves. Both caves are developed in carbonate rocks and determination of dominant mineralogical composition can explain some aspects of cave development. $\mathrm{X}$-ray diffraction allows a distinct differentiation between calcite $\mathrm{CaCO}_{3}$ and dolomite $(\mathrm{Ca}, \mathrm{Mg}) \mathrm{CO}_{3}$. XRD results show that samples taken from both caves have similar mineralogical composition. The dominant mineral in both samples is calcite which shows characteristic peak at $29.4^{\circ} 2 \theta$. Characteristic peak for dolomite is present at $30.9^{\circ} 2 \theta$. Smaller peak between $35^{\circ}$ and $50^{\circ} 2 \theta$ also peaks which originate from diffraction on calcite. Dominant peaks for quartz are at $26.6^{\circ}$ and $20.8^{\circ}$ $2 \theta$. The peak area intensities indicate the amount of the present crystalline quartz since amorphous silica adds only to the diffuse scattering, which, is the part of the background noise. The amount of calcite is more than $50 \%$ and the amount of dolomite is less than $1 \%$ in both rocks. Since calcite has a better solubility than dolomite, higher amount of calcite in rocks makes them more prone to dissolution and karstification under influence of water. The analysis of stone rock sections shows that carbonate rocks around Ali Sadr cave are predominantly made of crystalized calcite and considered a weak marble but the rocks in the Katale-Khor cave are biomicrite wackstones. The limestones of Ali-Sadr cave are impure with many insoluble constituents, which possibly intensify the acidity of the percolating water [45]. 
Water absorption percentage and porosity of the rocks in Katale-Khor cave is 3 to 7 times more than water absorption percentage and porosity of the rocks in Ali Sadr cave [47]. This all implicates that Ali Sadr cave is a hypogenic cave while the Katale-Khor cave is epigenic. In comparison to epigene karst systems which form in close interaction with the landscape and have both surface and underground elements, hypogene karst evolves without direct genetic connection with the surface, being initially characterized solely by void-conduit systems at depth [6].

\section{Conclusions}

Underground tourism is a relatively new and exotic form of geotourism. It enables untrained tourists to access before to them totally inaccessible areas of Earth's interior. If performed correctly and in accordance with principles of sustainability, geotourism is a good candidate for economically balanced tourism. The authors collected information about possibilities for underground geotourism in areas of Zanjan and Hamedan though direct research of the cave characteristics, compared them to existing published data and consequently filled the gaps in available data [6,51,56].

The Katale-Khor cave is formed in the body of Saqiz-lo Daghi mountain and in the Qom limestones of Oligo-Miocene age. In terms of design and pattern, the cave is of simple and anastomotic type. Ali-Sadr cave is developed in crystallized limestones and Jurassic schists. Ali-Sadr cave is one of the most unique and scenic caves in the world. One of the features that makes Ali-Sadr cave special is a fact that it is the longest and the biggest water cave in the world from the point of the boating course inside the cave.

The unique and attractive features of presented caves can make the local area very attractive for development of geotourism. In order to avoid serious and irretrievable damages of the phenomenon, detailed understanding of the phenomenon itself and the local geological conditions must be a priority. Better understanding of geological relations contributes to the establishment of better protective measures, which ultimately reflects on a better quality of life of the local population. All the activities should consider the need for sustainable development. Then again, resources should be made available in a such a way so that they serve both the local community and the region's visitors during the next decades.

Author Contributions: Conceptualization, D.D. and L.P.; methodology, A.A.; software, S.M.S.; validation, A.A., L.P. and B.Đ.; formal analysis, S.M.S.; investigation, D.D.; resources, AA.; data curation, S.M.S.; writing-original draft preparation, A.A.; writing—review and editing, D.D.; visualization, D.D.; supervision, A.A.; project administration, B.Đ. All authors have read and agreed to the published version of the manuscript.

Funding: This research received no external funding.

Institutional Review Board Statement: Not applicable.

Informed Consent Statement: Not applicable.

Data Availability Statement: Not applicable.

Conflicts of Interest: The authors declare no conflict of interest.

\section{References}

1. Garofano, M.; Govoni, D. Underground Geotourism: A Historic and Economic Overview of Show Caves and Show Mines in Italy. Geoheritage 2012, 4, 79-92. [CrossRef]

2. Cigna, A. Tourism and Show Caves. Z. Geomorphol. Suppl. Issues 2016, 60, 217-233. [CrossRef]

3. Kim, S.S.; Kim, M.; Park, J.; Guo, Y. Cave Tourism: Tourists' Characteristics, Motivations to Visit, and the Segmentation of Their Behavior. Asia Pac. J. Tour. Res. 2008, 13, 299-318. [CrossRef]

4. Safari, A.; Ghanbarloo, H.; Mansoury, P.; Esfahani, M.M. Reconstruction of the Depositional Sedimentary Environment of Oligocene Deposits (Qom Formation) in the Qom Basin (Northern Tethyan Seaway), Iran. Geologos 2020, 26, 93-111. [CrossRef]

5. Amrikazemi, A.; Abbas, M. Geotourism Resources of Iran. In Geotourism; Dowling, R.K., Newsome, D., Eds.; Elsevier ButterworthHeinemann: Burlington, MA, USA, 2006; pp. 78-92. 
6. Klimchouk, A.; Palmer, A.N.; Auler, A.S.; Auler, A.S.; Klimchouk, A.; Bezerra, F.H.R.; Cazarin, C.L.; Ennes-silva, R.; Balsamo, F. Hypogene Karst Regions and Caves of the World; Klimchouk, A.N., Palmer, A., De Waele, J.S., Auler, A., Audra, P., Eds.; Cave and Karst Systems of the World; Springer International Publishing: Cham, Switzerland, 2017; ISBN 978-3-319-53347-6.

7. Ghazi, J.M.; Ólafsdóttir, R.; Tongkul, F.; Ghazi, J.M. Geological Features for Geotourism in the Western Part of Sahand Volcano, NW Iran. Geoheritage 2013, 5, 23-34. [CrossRef]

8. Pásková, M. Environmentalistika Cestovního Ruchu (Tourism Environmentalism). Czech. J. Tour. 2012, 1, 77-113. (In Czech)

9. Dowling, R.K. Global Geotourism-An Emerging Form of Sustainable Tourism. Czech. J. Tour. 2014, 2, 59-79. [CrossRef]

10. Dowling, R.; Newsome, D. (Eds.) Geotourism's Issues and Challenges. In Geotourism; Elsevier Butterworth-Heinemann: Burlington, MA, USA, 2006; pp. 242-255.

11. Herrera-Franco, G.; Montalván-Burbano, N.; Carrión-Mero, P.; Apolo-Masache, B.; Jaya-Montalvo, M. Research Trends in Geotourism: A Bibliometric Analysis Using the Scopus Database. Geosciences 2020, 10, 379. [CrossRef]

12. Ólafsdóttir, R.; Tverijonaite, E. Geotourism: A Systematic Literature Review. Geosciences 2018, 8, 234. [CrossRef]

13. Widawski, K.; Jary, Z.; Oleśniewicz, P.; Owczarek, P.; Markiewicz-Patkowska, J.; Zaręba, A. Attractiveness of Protected Areas for Geotourism Purposes from the Perspective of Visitors: The Example of Babiogórski National Park (Poland). Open Geosci. 2018, 10, 358-366. [CrossRef]

14. Farsani, N.T.; Coelho, C.; Costa, C. Geotourism and Geoparks as Gateways to Socio-cultural Sustainability in Qeshm Rural Areas, Iran. Asia Pac. J. Tour. Res. 2012, 17, 30-48. [CrossRef]

15. Ahmadzade, M.; Elmizadeh, H. Geomorphological Evolution of Karst Cave in Katalekhor. In Proceedings of the 32nd National and the 1st International Geosciences Congress, Tehran, Iran, 18-19 February 2014; Geological Survey of Iran: Tehran, Iran, 2014.

16. Parise, M.; Gabrovsek, F.; Kaufmann, G.; Ravbar, N. Recent Advances in Karst Research: From Theory to Fieldwork and Applications. Geol. Soc. Spec. Publ. 2018, 466, 1-24. [CrossRef]

17. Zgłobicki, W.; Baran-Zgłobicka, B. Geomorphological Heritage as a Tourist Attraction. A Case Study in Lubelskie Province, SE Poland. Geoheritage 2013, 5, 137-149. [CrossRef]

18. Tomić, N.; Sepehriannasab, B.; Marković, S.B.; Hao, Q.; Lobo, H.A.S. Exploring the Preferences of Iranian Geotourists: Case Study of Shadows Canyon and Canyon of Jinns. Sustainability 2021, 13, 798. [CrossRef]

19. Robinson, A. Marketing Geotourism to Potential Australian Geotourists. Geoconserv. Res. 2018, 1, 28-36.

20. Grigorescu, D.A. From Scientific Research to Geoconservation and Geopark. Geoconserv. Res. 2020, 3, 8-31.

21. Arian, M. Physiographic-Tectonic Zoning of Iran's Sedimentary Basins. Open J. Geol. 2013, 3, 169-177. [CrossRef]

22. Map of Iran. Available online: d-maps.com/carte.php?num_car=5494\&lang=en (accessed on 12 May 2021).

23. Open Street Map. Available online: www.openstreetmap.org/\#map=8/28.530/46.450 (accessed on 12 May 2021).

24. Vernant, P.; Nilforoushan, F.; Hatzfeld, D.; Abbassi, M.R.; Vigny, C.; Masson, F.; Nankali, H.; Martinod, J.; Ashtiani, A.; Bayer, R.; et al. Present-Day Crustal Deformation and Plate Kinematics in the Middle East Constrained by GPS Measurements in Iran and Northern Oman. Geophys. J. Int. 2004, 157, 381-398. [CrossRef]

25. Nadimi, A. Evolution of the Central Iranian basement. Gondwana Res. 2007, 12, 324-333. [CrossRef]

26. Ahmadian, J.; Murata, M.; Nadimi, A.; Ozawa, H.; Kozai, T. Recent Tectonic Activity of Iran Deduced from Young Magmatism Evidences. Bull. Cent. Collab. Community 2014, 28, 23-38.

27. Alizadeh, S. Non-Diapiric Salt Domes in the West Zanjan, Central Iran. Open J. Geol. 2017, 7, 132-146. [CrossRef]

28. Jackson, M.P.A.; Cornelius, R.R.; Craig, C.H.; Gansser, A.; Stöcklin, J.; Talbot, C.J. Salt Diapirs of the Great Kavir, Central Iran; Memoir 177; Geological Society of America: Boulder, CO, USA, 1990.

29. Berberian, M. Active Tectonics and Geologic Setting of the Iranian Plateau. In Earthquakes and Coseismic Surface Faulting on the Iranian Plateau, a Historical, Social and Physical Approach, Developments in Earth Surface Processes; Berberian, M., Ed.; Elsevier: Oxford, UK, 2014; Volume 17, pp. 151-171. ISBN 9780444632920.

30. Ghorbani, M. Lithostratigraphy of Iran; Springer Geology; Springer International Publishing: Cham, Switzerland, 2019; ISBN 978-3-030-04962-1.

31. Aghanabati, A. The Geology of Iran; Geological Survey of Iran: Tehran, Iran, 2004; p. 586. (In Persian)

32. Reuter, M.; Piller, W.E.; Harzhauser, M.; Mandic, O.; Berning, B.; Rögl, F.; Kroh, A.; Aubry, M.P.; Wielandt-Schuster, U.; Hamedani, A. The Oligo-/Miocene Qom Formation (Iran): Evidence for an Early Burdigalian Restriction of the Tethyan Seaway and Closure of Its Iranian Gateways. Int. J. Earth Sci. 2009, 98, 627-650. [CrossRef]

33. Königshof, P.; Carmichael, S.K.; Waters, J.; Jansen, U.; Bahrami, A.; Boncheva, I.; Yazdi, M. Palaeoenvironmental Study of the Palaeotethys Ocean: The Givetian-Frasnian Boundary of a Shallow-Marine Environment Using Combined Facies Analysis and Geochemistry (Zefreh Section/Central Iran). Palaeobiodivers. Palaeoenviron. 2017, 97, 517-540. [CrossRef]

34. Raziei, T. Köppen-Geiger Climate Classification of Iran and Investigation of Its Changes during 20th Century. J. Earth Sp. Phys. 2017, 43, 419-439.

35. Kottek, M.; Grieser, J.; Beck, C.; Rudolf, B.; Rubel, F. World Map of the Köppen-Geiger Climate Classification Updated. Meteorol. Z. 2006, 15, 259-263. [CrossRef]

36. Raziei, T.; Daryabari, J.; Bordi, I.; Pereira, L.S. Spatial Patterns and Temporal Trends of Precipitation in Iran. Theor. Appl. Climatol. 2014, 115, 531-540. [CrossRef]

37. Bruckman, V.J.; Wriessnig, K. Improved Soil Carbonate Determination by FT-IR and X-ray Analysis. Environ. Chem. Lett. 2013, 11, 65-70. [CrossRef] 
38. National Iranian oil company Geological map of Iran. 1959. Available online: www.geographicus.com/P/AntiqueMap/ irangeologicalmap-iranoilcompany-1957 (accessed on 1 April 2021).

39. Raeisi, E.; Laumanns, M. Cave Directory Iran, 1st ed.; Berliner Höhlenkundliche Berichte: Berlin, Germany, 2003.

40. Rezaei, M.; Nakhaei, M. Genesis of Katalekhor Karstic Cave, Zanjan Province. Iran. J. Geol. 2008, 6, 11-19.

41. Mahmoudi Sivand, S.; Bgherinejad, R. Kataleh-Khor Karstic Cave in Zanjan Province (Iran), Hydrogeology and Mapping. In Proceedings of the International Conference on Water Resources: Emphasis on Regional Development, Shahrood, Semnan Province, Iran, 15-17 August 2009.

42. Dowling, R.K.; Newsome, D. (Eds.) Geoturism; Elsevier Butterworth-Heinemann: Burlington, MA, USA, 2006.

43. Ali Sadr Cave Photo. Available online: www.irandiamondtour.com/ArticleDetails/27/Hamadan-AliSadr-Cave (accessed on 1 April 2021).

44. Klimchouk, A. Hypogene Speleogenesis: Hydrogeological and Morphogenetic Perspective; National Cave and Karst Research Institute: Carlsbad, CA, USA, 2007; ISBN 9780979542206.

45. Kaufmann, G. Ghar Alisadr, Hamadan, Iran: First Results on Dating Calcite Shelfstones. Cave Karst Sci. 2002, $29,129-133$.

46. Ford, D.C.; Williams, P. Karst Hydrogeology and Geomorphology; Wiley: West Sussex, UK, 2007; ISBN 9780470060056.

47. Gobadi, M. The Role of Karst Geomorphic Study in Recognition of Cave Origins. Iran. J. Eng. Geol. 2012, 4, 40-47.

48. Frisia, S.; Borsato, A.; Fairchild, I.J.; McDermott, F.; Selmo, E.M. Aragonite-Calcite Relationships in Speleothems (Grotte De Clamouse, France): Environment, Fabrics, and Carbonate Geochemistry. J. Sediment. Res. 2002, 72, 687-699. [CrossRef]

49. Burton, E.A.; Walter, L.M. Relative Precipitation Rates of Aragonite and Mg Calcite from Seawater: Temperature or Carbonate Ion Control? Geology 1987, 15, 111-114. [CrossRef]

50. Mahmoudi Sivand, S. Hydrogeology of Katale Khor Cave report; Iran Karst Research Center: Shiraz, Iran, 2000. (In Persian)

51. Mahmud, K.; Mariethoz, G.; Baker, A.; Treble, P.C. Hydrological Characterization of Cave Drip Waters in a Porous Limestone: Golgotha Cave, Western Australia. Hydrol. Earth Syst. Sci. 2018, 22, 977-988. [CrossRef]

52. Genty, D.; Deflandre, G. Drip Flow Variations under a Stalactite of the Pere Noel Cave (Belgium). Evidence of Seasonal Variations and Air Pressure Constraints. J. Hydrol. 1998, 211, 208-232. [CrossRef]

53. Miorandi, R.; Borsato, A.; Frisia, S.; Fairchild, I.J.; Richter, D.K. Epikarst Hydrology and Implications for Stalagmite Capture of Climate Changes at Grotta di Ernesto (NE Italy): Results from Long-Term Monitoring. Hydrol. Process. 2010, 24, 3101-3114. [CrossRef]

54. Sherwin, C.M.; Baldini, J.U.L. Cave Air and Hydrological Controls on Prior Calcite Precipitation and Stalagmite Growth Rates: Implications for Palaeoclimate Reconstructions Using Speleothems. Geochim. Cosmochim. Acta 2011, 75, 3915-3929. [CrossRef]

55. Mohammadi, Z.; Claes, H.; Vassilieva, E.; Rudy, S. Key Hydrochemistry Parameters and Toxicity of Ali Sadr World's Largest Water Cave (Hamadan, Iran). In Proceedings of the 34th IAS Meeting of Sedimentology, Rome, Italy, 10-13 September 2019.

56. Safarabadi, A.; Shahzeidi, S.S. Tourism Silence in Geomorphosites: A Case Study of Ali-Sadr Cave (Hamadan, Iran). Geoj. Tour. Geosites 2018, 21, 49-60. 